\title{
Class Action Lawsuit on Civil Issues in Indonesia as Common Law Adoption
}

\author{
Maryana Lestari ${ }^{1}$, Septhian Eka Adiyatma ${ }^{2}$ \\ ${ }^{1}$ Faculty of Law, Universitas Muhammadiyah Yogyakarta \\ ${ }^{2}$ Faculty of Law, Universitas Negeri Semarang, Indonesia \\ Corresponding Author: S.E. Adiyatma, email: septhianekaa@gmail.com
}

\begin{abstract}
Regulations in Indonesia country must be fulfilled and adhered to, all the provisions in the form of prohibition, injunction and the sanctions that are in the environment of Indonesian society are legal countries. This research aims to analyze the discourse of class action lawsuit practices in Indonesian with comparing civil law system. The research also intended to illuminate the development civil law system practices in the context of class action practices. The research is doctrinal research with normative legal research. The research compared some legal theories concerning to class actions lawsuit in civil law system. The research highlighted and emphasized that the actions and deeds are led to occur harmonious society without touching the rights of others. In civil law issues include problems between individuals and groups and from group to group and individual to individual, who violated the rights and obligations as a result of an agreement. Expanding the law does not rule out a new legal innovation that can make a person who made a report the other party violated his rights in the absence of a prior agreement to do. The research concluded that the class action suit or action lawsuit is a legal order that is embraced by the common law system, but countries that use civil law systems like Indonesia participate adopt this legal order.
\end{abstract}

Keywords: Loss; Class Action Lawsuit; HIR; Common Law; Civil Law

\section{How to cite:}

Lestari, M., \& Adiyatma, S. E. (2020). Class Action Lawsuit on Civil Issues in Indonesia as Common Law Adoption. Indonesian Journal of Advocacy and Legal Services, 2(2), 243-260. https://doi.org/10.15294/ijals.v2i2.38171 


\section{A. Introduction}

Law civil event is a part of from civil law in formal terms with the procedure to be able to carry out a court system in order to obtain justice, civil disputes the result of a civil relationship that causes the party to feel the loss. Civil procedural law is intended for the public so that the guarantee of civil law can be adhered to as stipulated in the source of law. In general, the provisions in civil procedural law are not only related to the issue of non-fulfillment of an obligation as a body and develops in the community, but the civil procedural law is more directed towards the implementation and the process of maintaining or enforcement legal norms civil material in civil law sources.

Civil procedural law is a legal regulation that regulates how to ensure compliance with material civil law by the judge. In other words, civil procedural law is a legal regulation that determines how to guarantee the implementation of material civil law. More concretely, it can be said that the civil procedural law regulates how to submit claims for rights, examine, and decide upon them and the implementation of the decision. ${ }^{1}$. Claims of rights in this case are nothing but actions aimed at obtaining legal protection provided by the court to prevent eigenrichting or judicial acts themselves. The act of judging itself is an act of exercising rights according to its own will which is arbitrary without the consent of the other parties concerned so that it will cause harm. Therefore, this judgmental act alone is not justified if we are to fight for or exercise our rights ${ }^{2}$.

So that all the rights stipulated in the civil procedural law are more directed at the court system of justice, to resolve the problem with the help of a judge. The settlement process through the assistance of judges is aimed at restoring the rights of the injured party. The procedure for court proceedings cannot be arbitrary because it is complexly regulated in its legal sources which include the Het Herziene Indonesisch Regulations or HIR that only applies to the Java and Madura regions, the Rechtsreglement voor de Buitengewesten or the RBg that applies to areas outside Java and Madura, Law Number 48 of 2009 concerning Judicial Power, Law Number 3 of 2009 concerning the Supreme Court, Law Number 49 of 2009 concerning General Courts, and several other rules.

1 Benny Rijanto, Benny Rijanto, Modul 1 Sejarah, Sumber, dan Asas-asas Hukum Acara Perdata, Jakarta, Universitas Terbuka, 2018, pp. 15-17, retrieved from http://repository.ut.ac.id/4120/1/HKUM4405-M1.pdf. See also Endang Mustikowati, "Analisis Normatif Terhadap Pengajuan Gugatan Perwakilan Kelompok (Class Action) di Pengadilan Menurut Hukum Acara Perdata”, Jurnal Yustisiabel Vol. 3 No. 1, 2019, pp. 62-75.

2 Sudikno Mertokusumo, Hukum Acara Perdata Indonesia, Yogyakarta, Liberty, 1993, p. 2 
Literally, civil law divides the two major groupings to uphold the law. Every action regulated in civil law can be done while everything that is not contained in civil procedural law may not be done because it will have legal consequences. However, as the development of law both in Indonesia and in the world new legal actions will emerge that can be adopted by each legal system according to their respective rules. An example is the procedure for civil proceedings divided into lawsuits and requests that go to court. An application is only made by one party while a lawsuit is filed by two or more parties which proceed in court.

The state of Indonesia as a former colony of several countries such as Spain, Portugal, Britain, the Netherlands, and Japan made this country come from the adoption of several state laws that had colonized Indonesia. After the independence of regulations in Indonesia is still evolving to complete the regulations so that there is no legal vacuum, the development of a very rapid community to cope so that problems do not occur in the community is very necessary to regulate actions by the state thereby making the reasons why in Indonesia emphasizes the law at the cutting edge. Even so the legal journey in Indonesia is said to be quite slow compared to other developed countries, so that it is natural for adoption of law to be carried out by Indonesia as one example is a class action lawsuit. This lawsuit is outside the legal system adopted by Indonesia, because the Indonesian state is a follower of the civil law system while the class action lawsuit is the result of the common law system. This adoption is not only done once by Indonesia but even as a result of conventions in the world adopted by the Indonesian state as a whole into its regulations, but as the law develops in Indonesia some acculturations have been carried out with culture in Indonesia so that in the end the legal institutions adopted are not fully adopted from another legal system. ${ }^{3}$

\section{B. Method}

This research is doctrinal with normative legal research. This type of paper includes a paper on the law with regard to the problems that arise in social life to find solutions in recognition of the binding force of law to all walks of life and does not escape from the normative method because the explanation for legal proceedings in civil law must be in accordance with statutory provisions. This paper uses a number of approaches including the case approach or the case approach, the statutory approach or the statute

3 Julaiddin, and Henny Puspita Sari. "Citizen Lawsuit (Gugatan Warga Negara) Terhadap Penyelenggara Negara dalam Mencari Keadilan." UNES Journal of Swara Justisia Vol. 3 No.1, 2019, pp. 13-23. 
approach and the fact approach as is the case in the actual community or the fact approach ${ }^{4}$. This paper requires material consisting of primary, secondary, and other supporting data sources. The primary data source comes from the law, while secondary and supporting data are obtained from the results of research and other papers that discuss class action. In this case, the information obtained is processed and analyzed in depth by comparing the literature to obtain objective data.

\section{Result and Discussion}

\section{Lawsuit Systems in Indonesia and Its Development}

Before explaining the application of class action lawsuits in Indonesia, it is necessary to explain in advance class action lawsuits. Class action lawsuits or in this country are referred to as group representation lawsuits, at first the lawsuit was made but was rejected by the court for several reasons including:

1) The lawsuit is done not from the party who has an interest or have a legal relationship

2) The party who sues does not have a special power of attorney to represent, whereas based on HIR article 123 paragraph 1 it is stated that those who have no legal relationship are required to have a power of attorney to represent the interested parties

3) Indonesian state law does not yet adhere to class action lawsuits

4) Because the country of Indonesia uses a different system than the country that originated the class action lawsuit.

With these four reasons the lawsuit of the group's representatives was rejected by the court, but as a regulation that must keep abreast of the times and even be able to predict other legal actions that will emerge in the future the implementation of class action will also be applied in Indonesia.

A class action lawsuit is a method given to a group of people who have an interest in a problem, whether one or more of its members sues or is sued as a group representative without having to participate from each group member. ${ }^{5}$ The lawsuit of group representative/class action suit from the

4 Amirrudin Z. Asikin, Pengantar Metode Penelitian Hukum, Jakarta, Raja Grafindo, 2004, pp. 118-119.

5 Anonim, Class Action, June 20, 2003, retrieved from https://www.hukumonline.com/klinik/detail/ulasan/cl2436/class-action/. For more comprehensive comparison, please also see Moch Iqbal, "Aspek Hukum Class Action Dan Citizen Lawsuit Serta Perkembangannya di Indonesia", Jurnal Hukum dan Peradilan Vol. 1 No. 1, 2012, pp. 89-112; Rahadi Wasi Bintoro, "Tuntutan Hak dalam Persidangan Perkara Perdata", Jurnal Dinamika Hukum Vol. 10 No.2, 2010, pp 147-156; Muhammad Adiguna Bimasakti, "Merekonstruksi Paradigma Gugatan Citizen Lawsuit 
expert's point of view is unknown in the proceedings in civil law but because of the efficiency and economic factors, this is applied by Indonesia. In essence, group representation lawsuits are civil claims related to requests or compensation that may be brought to court by a number of people as representatives representing their interests. The legal basis for class action is based on Supreme Court Regulation No. 1 of 2002 concerning Group Representative Lawsuits, followed by several other rules such as the Consumer Protection Act, Law on Environmental Protection and Management, and Labor Law.

Considering article $123 \mathrm{HIR}$ paragraph 1, the use of power of attorney is mandatory but for group representation claims are excluded because of the Supreme Court Regulations. Because the group representation lawsuit is very special, but there are some requirements that must be obeyed so that the group representative's lawsuit can be accepted by the court including:

1) The number of group members increases so that it is ineffective and inefficient if the lawsuit is carried out individually or jointly in one lawsuit

2) There are similarities in facts or events and the basic legal similarities used that are substantial in nature, and there are similar types of claims between group representatives and group members

3) Group representatives have honesty and sincerity to protect the interests of the group members they represent. ${ }^{6}$

There are other views relating to the requirements for carrying out group representation lawsuits such as:

1) The number of group members is so large that it is ineffective and inefficient if the lawsuit is carried out individually or together in one lawsuit

2) There are similarities in facts or events and the basic legal similarities used that are substantial, as well as there are similar types of claims between group representatives and group members

3) Group representatives have honesty and sincerity to protect the interests of the group members they represent

Di Indonesia Sebagai Sengketa Administrasi." Jurnal Hukum \& Pembangunan Vol. 50 No.1, 2020, pp. 230-244.

6 Mungkid District Court, Gugatan Perwakilan Kelompok, 2015, accessed from the link: http://www.pn-mungkid.go.id/2015-06-06-01-33-28/gugatan-perwak-kel groups.html. See also I. Ketut Tjukup, and I. Gusti Ayu Agung Ari Krisnawati. "Penyelesaian Sengketa Melalui Upaya Litigasi di Bidang Penegakan Hukum Lingkungan Keperdataan." ADHAPER: Jurnal Hukum Acara Perdata Vol. 4 No.2, 2019, pp.163-185. 
4) Judges can encourage group representatives to replace lawyers, if lawyers take actions that are contrary to the obligations of defending and protecting the interests of their group members. ${ }^{7}$

Each lawsuit must meet the systemic, as well as group representative lawsuits, which must include them ${ }^{8}$ :

1) Complete and clear identity and group representation.

2) Group identity in detail without mentioning the name of the member.

3) Complete and clear identity of group representatives, without mentioning the names of the group members one by one.

4) Group identity required in connection with notification obligations.

5) Posita from all groups both group representatives and group members who were identified or not identified which were stated clearly and in detail.

6) Representative claims can be grouped into several groups or sub-groups, if the demands are not the same because of the different nature and loss.

7) Claims or petitum about compensation must be stated clearly and in detail containing proposals about the mechanism or procedure for distributing compensation to the whole group members including proposals on the formation of a team or panel that helps facilitate the distribution of compensation. ${ }^{9}$

After a lawsuit goes to court, the next process that will be carried out is almost similar with the lawsuit as usual, the following is a complete description based on what is used in each court:

1) At the beginning of the trial examination process, the judge must examine and consider the criteria for a group representative's lawsuit and provide advice to the parties about the requirements of a group representative's claim, then the judge provides a determination regarding whether or not the group's claim is legitimate.

2) If the use of the group representative's lawsuit procedure is declared valid, the judge immediately orders the plaintiff to propose a notification model to obtain judge approval.

3) If the use of the procedure for class representation lawsuit is declared invalid, the examination of the claim is terminated by a judge's decision.

4) In the case process, the Judge is obliged to encourage the parties to settle the case through peace, both at the beginning of the trial and during the case investigation.

Mungkid District Court, Ibid.

Ibid.

$9 \quad$ Ibid. 
5) The way to notify group members can be done through printed and / or electronic media, government offices such as sub-districts, villages or villages, court offices, or directly to the group members concerned as long as they can be identified based on the judge's approval.

Furthermore, it is also emphasized that notification to group members must be done at stages:

1) Immediately after the judge decides that the filing of the group representative's lawsuit is declared valid; and then group members can make an exit statement.

2) At the stage of settlement and distribution of compensation when the claim is granted.

3) Notification loading, including:

a. Claim number and identity of the plaintiff or the plaintiffs as group representatives as well as the defendant or defendant parties

b. A brief description of the case

c. Explanation of group definition

d. Explanation and implications of inclusion as a group member

e. An explanation of the possibility of group members included in the definition of the group leaving the group membership

f. Explanation of time, i.e. month, date, time, notification of exit statement can be submitted to the court

g. Explanation of the address intended to submit an exit statement

h. If needed by group members about who exactly is available to provide additional information

i. Fill-in forms regarding the statement of group members leaving as stipulated in the attachment to this Supreme Court Regulation

j. Explanation of the amount of compensation to be submitted.

4) After notification is given by the group representative based on the judge's agreement, the group members within the period determined by the judge are given the opportunity to declare their group membership by filling out the form set out in the appendix to this Supreme Court Regulation.

5) The party that has declared itself discharged from the membership of the group representative's lawsuit is not legally related to the decision on the group representative's lawsuit in question.

6) Claims for group representation were filed in environmental cases (Article 37 of Law No. 23 of 1997 concerning Environmental Management), Consumer Protection cases (Article 46 of Law No. 8 of 1999 concerning Consumer Protection), and forestry cases (Article 71 of Law Law No. 41 of 1999 concerning Forestry). 
7) In a class action claim, if the claim for compensation is granted, the judge is obliged to decide on the amount of compensation in detail, the determination of the group and / or sub-groups entitled, the mechanism for the distribution of compensation and the steps that must be taken by the group representative in the determination process and distribution as well as the obligation to make notifications or notifications (Article 9 PERMA). ${ }^{10}$

From the provisions of Article 1 letter a of the Supreme Court Regulation Number 1 of 2002 concerning Class Representative Claims, the requirements for group lawsuits are:

1) Numerosity, meaning that the number of plaintiffs is so large (can be tens, hundreds, even thousands of people) that it is impractical and inefficient if the lawsuit is filed individually and is therefore considered sufficient if the lawsuit is filed by one person or several people as group representatives (class representation) who represent as group members (class action);

2) Commonality, meaning that there must be similarity of facts and events and the legal basis (question of law) between the party representing and the party represented in the filing of the lawsuit

3) Typicality, meaning that there must be a common claim or defense of all members represented (class members)

4) Adequacy of Representation, meaning that there must be a feasibility of representation, namely requiring class of representatives to ensure that they are honest and fair and able to protect the interests of those they represent. ${ }^{11}$

Representative lawsuit is a new system adopted by the Indonesian state, so that many regulations in it do not stand alone because it must be adjusted to the existing rules so that there is no rule imbalance. Therefore, Supreme Court Regulation No. 1 of 2002 does not fully regulate the proceedings in response to claims by representatives who enter the court. Thus the presence of HIR and RBg is still in force, but there are a number of things that have been subjected to adjust to the lawsuit of representation such as the application of article 123 paragraph 1 is not fully enforced. A lawsuit

A lawsuitclass actionhas some differences from the usual lawsuit, although not much. These differences include the following:

10 Ibid. for another perspective, please also see Annisa Nur'Alam, and Devita Ayu Maharani. "Implementasi Gugatan Class Action di PTUN (Uji Pasal 2 Peraturan MARI No. 1 Tahun 2002 terhadap Asas Ius Curia Novit)." Gema Keadilan Vol. 7 No.2, 2020, pp 58-68.

11 Ujang Abdullah, "Gugatan Perwakilan Kelompok dan Hak Gugat Organisasi dalam Kaitannya dengan Kompetensi Pengadilan Tata Usaha Negara", Varia Peradilan Majalah Hukum, XXII (254), January, pp. 51-53. 
First, background (posita) and claim suitclass actionmade in depth and in detail. Posita must summarize the interests of groups identified and those that have not yet been identified. Lawsuitclass actionmust include the compensation mechanism desired by the Plaintiff. Whereas in the usual lawsuit the plaintiff experienced only and the claim for compensation was also immediately clear.

Second, after the lawsuit was filed by a group representative, the Judge conducted a certification process, namely checking whether or not the lawsuit could actually be submitted through the suitclass action. After being examined and deemed to meet the requirements, the Judge will issue a determination that the representative's claim is valid. This stage is not in the ordinary lawsuit process.

Third, the notification process. This process is carried out in various ways that are more effective so that all class members are aware of the lawsuitclass actionthe. There are two types of notification mechanisms that are known, namely the mechanismopt-inandopt-out. ${ }^{12}$

The development of law in Indonesia, made this country innovate to create its own law and try to leave the law from the legacy of the country that had colonized Indonesia. Changes to this regulation, aiming to increase values and norms in society can be applied as a whole. However, the adoption of existing laws in Indonesia is still being adopted for the new law. This can be seen from the Academic Paper for the Draft Law on Civil Procedure Law, in which there are still rules regarding group representation as a juridical basis. Forming a new law must prioritize the principles used as the purpose of legal reform, such as the Draft Law on Civil Procedures in order to create an efficient, inexpensive justice system.

\section{Effectiveness of Class Action Laws}

The development of class action in Indonesia is not immediately acceptable, because the civil procedural law rules that have been used for a long time are unable to cover actions contained in class action lawsuits or group representatives. But along with the development because many cases could be resolved by this method, in 2002 through the Supreme Court regulations a representative lawsuit could be filed. Although it must meet the requirements contained in these regulations.

Class action lawsuits developed for the first time in countries adopting a common law system, so it is only natural for difficulties to use this system

12 Thareq Akmal Hibatullah, Mengenal Lebih Dekat dengan Gugatan Class Action, September 20, 2018, accessed from https://bplawyers.co.id/2018/09/20/mengenal-lebihdekat-dengan-gugatan-class-action/ 
in countries adopting a civil law system. Because it is the result of adoption from a different legal system, it is not surprising that class action lawsuits follow the norms in Indonesia so that there are several elements that become provisions for class action lawsuits including:

1) Civil lawsuits Lawsuits in class action are included in the civil law field. The term lawsuit is known in civil procedural law as an action that aims to obtain the protection of the rights granted by the court to avoid attempts at vigilanteism (eigenechting). A lawsuit which is a form of claim for rights that contains a dispute, the parties are plaintiffs and defendants. Parties here can be individuals or legal entities. Generally, the demands in a civil suit are monetary compensation.

2) Class Representative Is one or more people who suffer losses who file a lawsuit while representing a more numerous groups of people. To become a group representative there is no need for a special power of attorney from group members. When a class action lawsuit is filed in court, the position of the Group representative is an active plaintiff.

3) Class members are groups of people in large numbers who suffer losses whose interests are represented by group representatives in court. If the class action is submitted to court, the position of the group members is as a passive plaintiff.

4) There is a loss to be able to submit a class action, both the representative group (class representative) and group members (class members) must really or actually experience a loss or termed concrete injured parties.

5) Similarities in events or facts and the legal basis There are similarities in facts (events) and similarities in the legal basis (question of law) between the party representing (class representative) and the party represented (class members). ${ }^{13}$

Class action suits have several types including:

1) Plaintiff Class Action and Defendant Class Action Viewed from the parties facing each other, in some countries class action can be divided into two types of action classes namely Plaintiff class action and Defendant class action. Plaintiff class action is a submission of a lawsuit by a representative for his own interests and the interests of the group in large numbers. Defendant class action is the filing of a claim in a representative manner by one or more appointed to defend their own interests and the interests of the group in large numbers. Countries such

13 Emerson Yuntho, Seri Bahan Bacaan Kursus HAM untuk Pengacara XI Tahun 2007 Materi: Mekanisme Class Action, p.2., accessed from the link: https://reference.elsam.or.id/wp-content/uploads/2014/09/Class-Action_SebuahPengantar.pdf. 
as Britain, Australia, India, the United States and Canada and Indonesia use Defendant class action.

2) Public Class Action and Private Class Action According to the interests of the protected party and who has the authority to prosecute it, in the state of Ontario Canada under the Ontario Law Reform Commission, class action lawsuits are divided into Public class actions and Private class actions. This distribution is based on who will represent to sue the court in the event of injustice to the wider community. Public class action is a class action filed against violations of public interest. This class action is proposed by government agencies that have the capacity (usually prosecutors/public prosecutors) where the government agency is not a member or part of a group that is directly disadvantaged. Private class action is a class action that is filed against violations of individual rights experienced by a large number of people. This class action is proposed by an individual, that is, by a person or persons who are part of a group on the basis of the similarity of legal issues and claims.

3) True Class Action, Hybrid Class Action and Spurious Class Action In addition to the two criteria for the division of class actions, America based on the Federal Rule of Civil Procedure in 1938 had divided class actions into three types of class actions namely true class actions, hybrid class actions and spurious classes action. True class action is a class action where in a group all members have the same interests or have rights that are obtained together and in the same case. Examples of this type of class action are the cases of consumers in housing who suffered damage to parts of their homes due to default from the developer and the claims filed were compensation. Hybrid class action is a class action in which there are a number of rights claimed by a group of people but the object of the lawsuit is to obtain a judge's decision regarding a claim against certain goods or property rights of the defendant. An example of this type of class action case is a deer horn-shaped car steering design that endangers its consumers in the event of an accident. Many victims have been involved in accidents due to the deer horn-shaped steering wheel. Therefore, both drivers who have or have not been in an accident can file a lawsuit with the car steering company, with several demands: there are those who demand that they be replaced with a safe design, there are those who demand other safe steering changes, and there are those who demand compensation in the form of money due to an accident. Spourious class action is a class action in which some interests of group members who are not related to each other in the same problem to a defendant. An example of this lawsuit is for example the existence of problems from a housing 
consumer. Block I consumers complained about the lack of clean water facilities as promised by the developer. Block II consumers complained about the lack of playgrounds and Block III consumers complained that there were no good road facilities. Block I, II, II consumers can file class action claims based on the problems they are experiencing. An example of this lawsuit is for example the existence of problems from a housing consumer. Block I consumers complained about the lack of clean water facilities as promised by the developer. Block II consumers complained about the lack of playgrounds and Block III consumers complained that there were no good road facilities. Block I, II, II consumers can file class action claims based on the problems they are experiencing. An example of this lawsuit is for example the existence of problems from a housing consumer. Block I consumers complained about the lack of clean water facilities as promised by the developer. Block II consumers complained about the lack of playgrounds and Block III consumers complained that there were no good road facilities. Block I, II, II consumers can file class action claims based on the problems they are experiencing. ${ }^{14}$

The presence of a class action lawsuit is really needed as evidenced by its presence of simple, fast, and low cost judicial principles that can be met. In addition, the benefits offered from group representation lawsuits include:

1) The litigation process becomes very economical (Judicial Economy) It is no longer a secret to the public that litigation in court will cost a lot of money. For the plaintiff, through a class action mechanism, the case costs and costs for lawyers become cheaper compared to an individual lawsuit, which is sometimes not in accordance with the amount of compensation to be received. Not a few parties (individuals) who discouraged to resolve the case, by filing a lawsuit to court because of the high cost of lawsuits and attorneys' fees. The benefit is not only felt economically by the plaintiff but also by the defendant, because by filing a class action lawsuit, the defendant only once paid a fee to serve the lawsuit from the injured parties. As for the court itself, it is very uneconomical if it has to serve similar claims one by one and continuously and in large enough quantities.

2) Access to justice Filing a class action claim will be easier than filing a lawsuit individually. Joining together will reduce barriers for individual plaintiffs who are generally in a weak position, both in economic terms and in terms of (psychological) abilities and knowledge of law. Also, in

14 Ibid. 
class action does not require identification of names, so as to prevent intimidation of class members. Class action also prevents the repetition of case proceedings and prevents different decisions or inconsistent decisions when an individual lawsuit is made.

3) Encouraging caution (Behavior Modification) and changing the attitude of the offender Submitting a class action suit can "punish" the person found guilty, responsible for paying compensation in the amount intended for all victims (in a more concise manner) as a result of acts against the law he does. This can encourage each party or business person (private or government) to act extra carefully. Apart from that, class action is often proposed to change the attitude of violators so as to foster a deterrent attitude for those who have the potential to harm the interests of the wider community. ${ }^{15}$

In Indonesia, class action lawsuits adhere to article 37 of Law Number 23 of 1997 concerning Environmental Management, stating that the right to file a claim by group representatives can be carried out on environmental issues as long as the loss is incurred, Law Number 13 of 2003 concerning manpower and Law No. 8 of 1999 concerning Consumer Protection. But Law No. 14/1970 concerning Judicial Power Provisions states that it must use a small, fast and simple cost, so the presence of class action is very necessary. Thus the class action lawsuit is very effective to do in Indonesia,

A lawsuit for group representation or class action has a positive and negative impact if it is done, it cannot be denied that every legal action always displays consequences that will always be felt without exception including the use of representative claims to resolve. A claim for representation does represent each party whose interests are disturbed, but behind that representation there are results obtained both from the party representing the party being represented. By grouping into 4 representatives including Numerosity, the group in question is a large number of members so that the union into a group is reasonable; Commonality, There are similarities in legal issues or facts from all members represented; Typicality, There are similarities in demands and defense of all members represented; ${ }^{16}$.

It is undeniable that class class lawsuits class members generally receive small amounts of compensation, or often in the form of insignificant shopping vouchers or the production of products from the defendant

15 Ibid., p. 5

16 Laras Susanti, "Materi dan Prosedur Gugatan Perwakilan Kelompok: Studi Perbandingan Indonesia dan Amerika Serikat", Mimbar Hukum Vol. 30 No. 2, 2018, pp. 353-354. 
responsible, when compared to the class representative or attorney (attorneys fee) is very large, If a peace settlement (class settlement) with the defendant can be reached, class members can only receive a very small profit from the outcome of the peace, and Settlement of disputes through class action is felt to be unfair for group members who are not aware of the claim of the claim. ${ }^{17}$

The use of a class action lawsuit system to reduce the cost of a trial because the plaintiff and the defendant will experience a reduction in the cost of the case because of some of the same problems put together, provide access to justice to weak parties and have obstacles in order to fight for their rights in court, and enforce regulations so that it's simple, fast and costs less.

Because the lawsuit is carried out in a representative manner, the process of sharing the results is really needed by this distribution of compensation must be considered to which party gets as given directly to each group member, with the relevant conditions proving himself as a member of the group participating in the loss and can also go through subgroups (if any) without reducing the need to prove that they are victims of the alleged case. ${ }^{18}$

\section{Conclusion}

Due to its efficiency and economic factors, this is applied by Indonesia, and law enforcement is simple, fast, and low-cost, the presence of the application of class action lawsuits is necessary because basically class action or representative lawsuits are intended to cut or trim civil matters who was massively harmed. Although this action is an adoption of a legal system that is different from the legal system in Indonesia, the efforts of the Indonesian state to improve the justice system are visible. The lawsuit for group representation in Indonesia is still considered new because there are only 3 laws that regulate it with three main subjects of the Law such as consumer protection, environmental management and employment. But the efforts of the Indonesian state did not stop there; it is evident that in the Supreme Court regulations also participated in upholding the existence of class action lawsuits. The basis for filing this lawsuit is due to the protection of the injured party and has a weakness to file the lawsuit, although it is contrary to article $123 \mathrm{HIR}$ which is required if represented, it is necessary to show a special

17 Priska Debora Samosir, Dike Widhyaastuti, I Gusti Agung Ayu, "Tujuan Dan Manfaat, Serta Kritik Yang Timbul Dari Gugatan Perwakilan Kelompok (Class Action) Dalam Suatu Sengketa Perdata di Indonesia", Kertha Wicara: Journal Ilmu Hukum, Vol. 5 No. 5, 2016, pp. 1-6. https://ojs.unud.ac.id/index.php/kerthawicara/article/view/24809

18 Sovia Hasanah, Cara Pembagian Ganti Rugi dalam Gugatan Perwakilan Kelompok (Class Action), retrieved from link: https://www.hukumonline.com/klinik/detail/ulasan/lt5962da2ee7b76/cara-pembagianganti-rugi-dalam-gugatan-perwakilan-kelompok-iclass-action-i/ 
power of attorney. Criticism and become a separate part of the validity of this lawsuit process. In addition, the efforts of the Indonesian state can be seen from the process of renewing the basis of civil procedural law by placing group representation lawsuits as part of a judicial basis, seeing that it can be predicted that the application of class action lawsuits can be fully carried out with the same goal of protecting the rights of the injured party. The basis for filing this lawsuit is due to the protection of the injured party and has a weakness to file the lawsuit, although it is contrary to article $123 \mathrm{HIR}$ which is required if represented, it is necessary to show a special power of attorney. Criticism and become a separate part of the validity of this lawsuit process. In addition, the efforts of the Indonesian state can be seen from the process of renewing the basis of civil procedural law by placing group representation lawsuits as part of a judicial basis, seeing that it can be predicted that the application of class action lawsuits can be fully carried out with the same goal of protecting the rights of the injured party. The basis for filing this lawsuit is due to the protection of the injured party and has a weakness to file the lawsuit, although it is contrary to article $123 \mathrm{HIR}$ which is required if represented, it is necessary to show a special power of attorney. Criticism and become a separate part of the validity of this lawsuit process. In addition, the efforts of the Indonesian state can be seen from the process of renewing the basis of civil procedural law by placing group representation lawsuits as part of a judicial basis, seeing that it can be predicted that the application of class action lawsuits can be fully carried out with the same goal of protecting the rights of the injured party. although contrary to article $123 \mathrm{HIR}$ which is required if represented, it is necessary to show a special power of attorney. Criticism and become a separate part of the validity of this lawsuit process. In addition, the efforts of the Indonesian state can be seen from the process of renewing the basis of civil procedural law by placing group representation lawsuits as part of a judicial basis, seeing that it can be predicted that the application of class action lawsuits can be fully carried out with the same goal of protecting the rights of the injured party. although contrary to article 123 HIR which is required if represented, it is necessary to show a special power of attorney. Criticism and become a separate part of the validity of this lawsuit process. In addition, the efforts of the Indonesian state can be seen from the process of renewing the basis of civil procedural law by placing group representation lawsuits as part of a judicial basis, seeing that it can be predicted that the application of class action lawsuits can be fully carried out with the same goal of protecting the rights of the injured party. 


\section{E. Acknowledgment}

Authors would like to thank to colleagues at Lex Scientia Community at Faculty of Law Universitas Negeri Semarang, as well to Research Community at Universitas Negeri Semarang for their suggest on discussing this paper.

\section{F. Declaration of Conflict of Interest}

The author states that there is no potential conflict of interest in the research, authorship, and/or publication of this article.

\section{G. Funding}

The author does not obtain financial support from any party for research, authorship, and/or publication of this article.

\section{H. References}

Abdullah, U. (2015). Gugatan Perwakilan Kelompok dan Hak Gugat Organisasi dalam Kaitannya dengan Kompetensi Pengadilan Tata Usaha Negara. Varia Peradilan Majalah Hukum, XXII (254), January, 51-68.

Anonim (June 2003). Class Action, retrieved from https://www.hukumonline.com/klinik/detail/ulasan/cl2436/classaction/

Asikin, A. Z. (2004) Pengantar Metode Penelitian Hukum. Jakarta: Raja Grafindo.

Bimasakti, M. A. (2020). Merekonstruksi Paradigma Gugatan Citizen Lawsuit di Indonesia Sebagai Sengketa Administrasi. Jurnal Hukum \& Pembangunan, 50(1), 230-244.

Bintoro, R. W. (2010). Tuntutan Hak dalam Persidangan Perkara Perdata. Jurnal Dinamika Hukum, 10(2), 147-156.

Hibatullah, T.A. (September 2018). Mengenal Lebih Dekat dengan Gugatan Class Action, retrieved from https://bplawyers.co.id/2018/09/20/mengenal-lebih-dekat-dengangugatan-class-action/

Hasanah, S. (July 2017). Cara Pembagian Ganti Rugi dalam Gugatan Perwakilan Kelompok (Class Action), retrieved from https://www.hukumonline.com/klinik/detail/ulasan/lt5962da2ee7b76/ cara-pembagian-ganti-rugi-dalam-gugatan-perwakilan-kelompokiclass-action-i/ 
Iqbal, M. (2012). Aspek Hukum Class Action dan Citizen Lawsuit Serta Perkembangannya di Indonesia. Jurnal Hukum dan Peradilan, 1(1), 89-112.

Julaiddin, J., \& Sari, H. P. (2019). Citizen Lawsuit (Gugatan Warga Negara) Terhadap Penyelenggara Negara dalam Mencari Keadilan. UNES Journal of Swara Justisia, 3(1), 13-23.

Mertokusumo, S. (1993). Hukum Acara Perdata Indonesia. Yogyakarta: Liberty.

Mungkid District Court. (2015). Gugatan Perwakilan Kelompok, retrieved from http://www.pn-mungkid.go.id/2015-06-06-01-33-28/gugatanperwakilan-kelompok.html

Mustikowati, E. (2019). Analisis Normatif Terhadap Pengajuan Gugatan Perwakilan Kelompok (Class Action) di Pengadilan Menurut Hukum Acara Perdata. Jurnal Yustisiabel, 3(1), 62-75.

Nur'Alam, A., \& Maharani, D. A. (2020). Implementasi Gugatan Class Action di PTUN (Uji Pasal 2 Peraturan MARI No. 1 Tahun 2002 terhadap Asas Ius Curia Novit). Gema Keadilan, 7(2), 58-68.

Republic of Indonesia. (1970). Law Number 14 of 1970 Concerning the Provisions of Judicial Powers [Undang-Undang Nomor 14 tahun 1970 Tentang Ketentuan-Ketentuan Kekuasaan Kehakiman], available at http://www.dpr.go.id/dokjdih/document/uu/UU_1999_35.pdf

Republic of Indonesia. (1997). Law Number 23 of 1997 concerning Environmental Management [Undang-Undang Nomor 23 tahun 1997 tentang Pengelolaan Lingkungan Hidup], available at http://sipongi.menlhk.go.id/cms/images/files/1026.pdf

Republic of Indonesia. (1999). Law Number 8 of 1999 concerning Consumer Protection [Undang-Undang Nomor 8 tahun 1999 tentang Perlindungan Konsumen], available at https://jdih.bsn.go.id/produk/detail/?id=380\&jns $=2$

Republic of Indonesia. (2003). Law Number 13 of 2003 concerning Manpower [Undang-Undang Nomor 13 tahun 2003 tentang Ketenagakerjaan], available at https://peraturan.bpk.go.id/Home/Details/43013

Republic of Indonesia. (2002). Supreme Court Regulation Number 1 of 2002 concerning Class Action Procedures [Peraturan Mahkamah Agung Nomor 1 tahun 2002 tentang Acara Gugatan Kelompok], available at https://putusan3.mahkamahagung.go.id/direktori/download_file/e9f7 7e621ff706ed7b437f5ecd2f64c9/pdf/3d344cb3b2e87de4cdbf3eb242d6 d654

Rijanto, B. (2018). Modul 1 Sejarah, Sumber, dan Asas-asas Hukum Acara Perdata. Jakarta: Universitas Terbuka. Retrieved from link: http://repository.ut.ac.id/4120/1/HKUM4405-M1.pdf.

Samosir, P. D., Widhyaastuti, Do., \& Ayu, I. G. A. (2016). Tujuan Dan Manfaat, Serta Kritik Yang Timbul Dari Gugatan Perwakilan Kelompok (Class Action) Dalam Suatu Sengketa Perdata di Indonesia. Kertha Wicara: Journal Ilmu Hukum, 5(5), 1-6. https://ojs.unud.ac.id/index.php/kerthawicara/article/view/24809 
Susanti, L. (2018). Materi dan Prosedur Penetapan Gugatan Perwakilan Kelompok, Studi Perbandingan: Indonesia dan Amerika Serikat. Mimbar Hukum, 30(2), 346-360.

Tjukup, I. K., \& Krisnawati, I. G. A. A. A. (2019). Penyelesaian Sengketa Melalui Upaya Litigasi di Bidang Penegakan Hukum Lingkungan Keperdataan. ADHAPER: Jurnal Hukum Acara Perdata, 4(2), 163185.

Yuntho, E. (2007). Seri Bahan Bacaan Kursus HAM untuk Pengacara XI Tahun 2007 Materi: Mekanisme Class Action. Jakarta: eLSAM, retrieved from https://referensi.elsam.or.id/wpcontent/uploads/2014/09/Class-Action_Sebuah-Pengantar.pdf 